\title{
From "Double Negative"
}

\section{Betsy Warland and Daphne Marlatt}

"Double Negative" was orginally written on a three-day train trip across the Australian continent from Sydney to Perth. It was written as a series of alternating lyric entries in a notebook, our only ground rule being that we had to use the names of places we were travelling through as we were writing. This, of course, made the poem narrative from the outset. Our common motive in writing was to invent a woman's version of the long train poem and discover how the train, traditionally a phallic symbol, might be imaged in female sexual terms. After we got back to Canada and took a second look at what we had written, we realized that the desert (our route ran through the Nullarbor) was as much the subject of our writing as the train. So we decided to write a prose sequel, "Real 2," that would break the narrative frame, get off the track, and explore the desert and what it meant to us. Our ground rules for this collaboration were that we would work through our first collaboration, each writing on the other's entries in sequence, and that we would take phrases from each other's entries as titles for our own prose texts. This immediately pushed us into a more theoretical mode, as our subject then became each other's words rather than objects (towns, people, fauna and flora) outside the writing or (to use a train metaphor) the writing was passing through. Indeed this writing wanted to walk around in what is decidedly not an inert landscape (take language as landscape) and saw as problematic any fixed distinction between subject and object. In this series of excerpts, we juxtapose lyric entries with the prose texts generated from them.

Sources: Elspeth Huxley quoted in Bob Reiss, "Crossing Southern Australia with the 'Tea \& Sugar'," Smithsonian XVII, 3; Jane Rule, Desert of the Heart. 


\title{
30/5 8:50
}

\section{past Menindee}

passed at night through

Nellungaloo, Derriwong, Micabil

dense mallee scrub

saltbush, belah, rose wood scrub

rock words tumbling dream

rocked sheep/sleep

rolled in our bunks

me above you below

in our ANR plaid blankets, no

rolled in the original glow our bodies

in the one berth sun and train smell on our

skin, soft, red earth soft

mounds of breast, belly

radiant in the womb-

motion of this

holding

train

\author{
traine, to \\ feminize (part of \\ a(d)dress) \\ and not merely in tow \\ you, you who know
}

we go inside

out

into the womb of the continent

ochre, red earth, salt plain 
evening the pink

rim of the dark the Darling

cuts an artery through, we stare in the

light, looking for kangaroo

bouncers, both

feet on the ground

prim paws, perked ears, they pound

the rim of the real their territory

we their dream roar through

staring, "i don't believe it"

we who are gone

into the realm of the disappeared

un/

original here

minus the smell of earth, the glisten

of mudhole in the light, the ground

eye view of bilby, ant

thirst, dust

a dream

we no longer remember

dingo talk didgeridoo style

(mimicked at Central Quay by a street hawker performing "the real thing" for the kids

who do perhaps remember

"from the beginning"

$\mathrm{ab} /$ original

we use their words for things, places

and they are different in our mouths

the oldest living language group in the world we don't know where they came from

we can't go back

not to the roots we know

Indo-European words, dead wood

sentences tracking

across the untracked, the

intractably here 


\section{"the rim of the real their territory"}

the "roos" stare back sometimes retreat bouncing away from the claim of our gaze ricochet off our invading reality tail's forceful push on red earth like our eyes evade glance off city sidewalks ("think I'll get me some tail") or in the night licking dew off the road mesmerized by headlights farmers with their "roo bars" protection from the impact of colliding realities steel fist drives on which reel are you in the "abos" stare back sometimes retreat their gaze not noosed by a written language (that's what you say) or it is Dreamtime a vision we can only imagine in theories like collective memory whatever it is they see differently until them $i$ had not known the power of a culture shapes the substance of our eyes makes us citizens on a cellular level yet there are aberrations mute mutations whose ocular language goes largely undetected by the linguistic mass the muscles between the eyes $\&$ tongue straining to translate stutter bewildering syntax synapse of alternate routes while He insists on "chicks" "roos" "abos" ("only nicknames, mate") sells His picture collage postcards of Australia's exotic animals: emu, kangaroo \& Aboriginal in the desert in the margin the "wild zone" losing the proper train of thought off the track the kanyala stare back and we see ourselves not reflected but re/called out of this kangaroo court re/called out of the Fathers' optical illusions changing the reel inside out into the womb of the continent ochre, red earth, salt plain the wheels turning below us the factual wheels of our knowing that move us for words to the rim of our writing from the centre of our speaking the intractably here what is woman (in the desert)? 


\section{$13: 05$}

\section{Mannahill}

none of either

saltbush, mallee, mulga dotting earth's red skin "scrub" and "plain"

scrubbed clean from plain as day she's just a plain Jane

who lives here

stares back unseen from windows we flash past

we in constant motion lulled by the movement carrying us forward into ourselves

we are fed we sleep are held nameless and content

umbilical track leading us to names on paper

Yunta, Paratoo, Ucolta, Yongala

words we head for down this birthing canal

"the oldest living language" shaping our tongues lips

to speak it out (though we do not know the meanings)

magnetic field of sounds

mouths move in anOther motion 


\section{"stares back unseen"}

to lift some words (up off the page) pick them up and run with them (here) to cite to quote is to move into fiction as if it isn't here she stares back unseen sighted/sited. "the man's job at least takes him out of that square kiln of a dwelling. . " seeing out of what we haven't or as glimpses (dreams) his wife is in the moving window frame extinguishing a fire her thirst to see a different actual - fiction cited here in light of what she lives:

"stuck day after day, week after week, in the square metal box, with a brood made fractious by heat." Jane or Joan or Janet several variations under one roof (galvanized tin). in that cinematic light it's her hands on the table raised in an o amazing what's she brought in now? not another joey lifted from dead kanga's pocket on the highway. "we were always bringing them home and most of them died, poor things." the actual she's remembering, actually Janet not some dictionary entry.

it's not words/it's in words moved by the very sound of mallee leaves angled downward from the sun (a droop even the stoop describes) red earth fragrance of the very dry the salt (bush) the fire scarred (seeds that will only germinate then) all fiction to the unexposed what is accessed: the $\mathrm{X}$ posed, situated so as to mark the sport and not unrelated to us. setting bread on the table it's plain Jane we've been here before making a home in the desert dreaming more than survival dreaming domestic paradise in the heart of the lost. as if there could be some arrangement with/in the unarranged the deranged the out on the range (target practice as a kind of sport). as if, as if (wishes were camels and we could ride) off into our own making. 


\section{$14: 50$}

\section{Peterborough}

we carry it with us

manna a kind of dew

falling from heaven as water does

as yours do

you remember Katoomba's "falling waters" or "the falling together of many streams"

freshness spraying our faces as we

nosed in behind its

grass-tree banksia fern

you said they were us, the mountains

unimaginable here though here changes in a sentence glancing off Peterborough wheat fields - this?

dry stubble glistening afternoon sheep

wool gathering, light thoughts

scatter as we clack by

(we are

(them

stubble legs on the table in the sun

indulgences (Schweppes soda water in its black and gold can

the royal we

(royal palms in a backyard

Jamestown now, after the Governor

glancing off, gazing out 
but we are not

apart from it

's incessant stream

the landscape pours through

us filled with it, held and

rocked backward, content or not

kinetic at all points in touch

with coming incessantly

into

THIS, this

image cattle climb the

soft mound of hill lost

dip or cleft a

$\mathrm{V}$ to view

"this little entry"

"mine take forever"

take forever

crossed then by

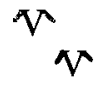

(a cloud, rose-breasted

this the imaginary

we enter 


\section{"light thoughts"}

shudder of the train heading for the heart CAMERA: "room" in your hands my shutter opening and closing $\mathrm{X}$ posing negatives in the womb obscura night $\mathrm{i} / \mathrm{s}$ focus through anOther window-lens camera within camera womb within room we "PHOTO, light + -GRAPH, to write" the FILM: "pel-, skin" our bodies (all ova carry X chromosomes) Tri-X "light sensitive" Jane writing of Evelyn first seeing the desert as "empty" (negative space) how can this barrenness team with life how can this once have been sea bottom-the desert unbelievable, dangerous (what is woman?) but we are not apart from it Jane's protagonist seeing that "The earth's given out. Men can't get a living from it. They have to get it from each other." the desert a different economy (her own woman?) yet there's uranium to be mined, sacred aboriginal sites to plunder Ann seeing "beauty" yet Evelyn doubtful (no place free from this violent taking) Jane at the table thinking desert thinking desire the two she writes driving out into it away from casino cathedrals to a like of "a blue so deep" no trees "nothing. . . but an Indian reservation" the alkaline water "Lovely for swimming" lake not worth developing where women's desire $\mathrm{X}$ changes into a foreign current/cy "Men can't get a living from" desert dune-wave currents

but we are not

apart from it

's incessant stream

"Your could almost imagine there were no other people" Jane at her table typing "lightning" "large drops" and "The storm bellied over them" as mine gathers around you in this room within a room this text within a text through this "treeless plain" Jane punching out the keys what is woman (in her own fiction)? 